\title{
Waste - valuables - secondary resources - contaminants - waste again?
}

Henning Friege

'Closing the loop' numbers among the confessions of environmental policy. And it is true: Without getting out resources from waste, some naturally scarce resources will run out of supply very early. Material recovery mostly saves energy in comparison to the production out of primary materials.

Societies with severe lack of resources were always acquainted to re-use and recycling to extend their own life and welfare. These societies learned to collect used products and how to gain valuable parts or substances from waste.

In the last century, this was a typical situation for many countries in Eastern Europe with lack of foreign currency due to an uncompetitive national economy. In these cases, regional recycling markets became a big issue. Industrial by-products were steered into other industries as secondary raw materials; the reclamation of recyclables from households was fostered by high purchase prices to be paid by official collection points.

Today, industrial societies all over the world are busy in recycling activities, some nations in Europe being in front of this movement. The globalization of primary resources and product streams is complemented by an increasing global market of secondary resources. The global trade with products conforms to some important rules which have been written down in multilateral trade agreements to preserve economic and fiscal interests. National and European regulations have been introduced to protect consumers against hazardous compounds in products focussing, for example, on toys, toiletries and electronic equipment.

But what about valuables in waste like used paper and cardboard, plastic packaging, plastic casings and printed circuit boards? These valuables are collected, sometimes together with other waste items, and recycled in sorting facilities. When material recycling is too expensive or

Correspondence: henning.friege@tu-dresden.de

Scholtenbusch 11, Voerde D-46562, Germany very difficult from a technical point of view, energy recovery from combustible waste is the best choice.

A lot of waste which cannot be recycled in Europe is exported, mostly to Asia, where products may be subjected to requirements less stringent than in Europe. Secondary raw materials come back into the product chain again as parts or ingredients of new products, furthermore contaminated by substances from the waste stream, which might have been useful in the 'first life', but not in the 'second life'. Recycled cardboard, used as packaging material for pasta, has become a prominent example for secondary contaminations. In this case, mineral oils which had been applied as solvents for inks in newspaper printing are not welcome in packaging because they migrate into the food [1].

Secondary resources might become waste due to contaminations. Risks might increase by the global trade of secondary resources. 'No threats to human health' is another confession even more important than 'closing the loop'. Neither wasting resources nor exposure to hazardous contaminants is a target for the intelligent management of substance chains.

The important questions are as follows: What is happening on the global market with respect to secondary resources? How do national governments regulate the recycling of potential valuables from waste? How are people protected against hazardous compounds in products? What is the significance of contaminants in products made from secondary resources? What do we know about the separation of hazardous compounds from industrial or household waste?

Some of these questions have been addressed in the RISKCYCLE project [2], which has been funded under the 7th Framework Program of the European Community, bringing together scientists from seven European countries and four countries in Asia and South America. RISKCYCLE focussed especially at the additives used in consumer and industrial products. Many potential hazardous compounds are traded worldwide as additives in different products. In this project, the fate in and after 
the use phase and also the behaviour of additives in the following six sectors were investigated in detail: textile, electronics, plastics, leather, paper and lubricants industry. Additives, being very useful in a certain industrial production, may be a threat to consumers if they migrate via recycling streams into other products. It is very difficult to obtain an overview of the enormous market of additives varying also between countries with different industrial standards. The idea behind RISKCYCLE was an intensive information exchange about the additives used, their environmental behaviour, their fate in waste streams. The final goal would be a conceptual development of a global strategy for risk-based management of chemicals and additives in recycling products [3].

Environmental Sciences Europe will publish several outcomes achieved in the project. Moreover, the steering group of the project is issuing two books in the series The Handbook of Environmental Chemistry, one has already been published and the other one being in preparation and will be available soon [4].

Received: 26 November 2012 Accepted: 5 March 2013

Published: 1 May 2013

\section{References}

1. Übergänge von Mineralöl aus Verpackungsmaterialien auf Lebensmittel. http://www. bfr.bund.de/cm/343/uebergaenge_von_mineraloel_aus_verpackungsmaterialien_ auf_lebensmittel.pdf.

2. RISKCYCLE. www.wadef.com.

3. Bilitewski B: The circular economy and its risks. Waste Management 2012. 32(1):1-2.

4. Bilitewski B, Darbra RM, Barceló D: Global Risk-Based Management of Chemical Additives I. Berlin: Springer; 2012.

doi:10.1186/2190-4715-25-9

Cite this article as: Friege: Waste - valuables - secondary resources -

contaminants - waste again?. Environmental Sciences Europe 2013 25:9.

\section{Submit your manuscript to a SpringerOpen ${ }^{\odot}$} journal and benefit from:

- Convenient online submission

- Rigorous peer review

- Immediate publication on acceptance

- Open access: articles freely available online

- High visibility within the field

- Retaining the copyright to your article

Submit your next manuscript at $\gg$ springeropen.com 